\title{
Etiological agents of bovine mastitis in Poland')
}

\author{
HENRYK KRUKOWSKI, HENRYKA LASSA*, EWA ZASTEMPOWSKA**, \\ SEBASTIAN SMULSKI***, HANNA BIS-WENCEL
}

\author{
Department of Microbiology and Reproductive Biology, Faculty of Biology, Animal Sciences and Bioeconomy, \\ University of Life Sciences, Akademicka 13 Str., 20-950 Lublin, Poland \\ *Milk Testing Laboratory, Faculty of Natural Science, Kazimierz Wielki University, \\ Chodkiewicza 15 Str., 85-065 Bydgoszcz, Poland \\ **Department of Physiology and Toxicology, Faculty of Natural Science, Kazimierz Wielki University, \\ Chodkiewicza 30 Str., 85-064 Bydgoszcz, Poland \\ ***Institute of Veterinary Sciences, Poznan University of Life Sciences, Wołyńska 35 Str., 60-637 Poznań, Poland
}

\section{Krukowski H., Lassa H., Zastempowska E., Smulski S., Bis-Wencel H. Etiological agents of bovine mastitis in Poland}

\section{Summary}

This research paper addresses the hypothesis that the incidence of various bovine mastitis pathogens is subject to change over time and across regions. The aim of the research was to determine the pathogen species that are currently the etiological agents of mastitis in Polish dairy herds. This comprehensive study was conducted in the period 2009-2017 and included all the Polish provinces, distinguishing between those with high and low numbers of dairy cattle. Over eight years 38,852 quarter milk samples were obtained from 22,587 cows with clinical and subclinical mastitis from herds located in all 16 provinces in Poland. Milk samples were cultured using standard microbiological methods. Most of them were positive for microorganisms but there was also part of bacteriologically negative and contaminated samples. Gram-positive catalase-negative cocci and staphylococci were the most prevalent pathogens. The growth of other microorganisms such as Gram-negative and Gram-positive bacilli, yeasts and algae was observed at lower frequencies. There were differences in the prevalence of microorganisms depending on the region. In the eastern part of the country a higher number of Streptococcus agalactiae infections than in other regions was observed. This paper provides the latest data on microbial species, frequency of their occurrence and regional location within Poland. The knowledge of mastitis pathogens enables appropriate treatment and to make prevention recommendations for the herds.

Keywords: etiological agents, mastitis, dairy cow

Mastitis in cows is caused by the simultaneous occurrence and overlap of many unfavorable factors of which the most important are pathogens. The etiological agents that cause mastitis may vary depending on the climate, species or breeding. These agents include a wide range of Gram-positive and Gram-negative bacteria, mycoplasmas, fungi, yeasts, algae and viruses. According to Watts (35), the inflammation of the udder is caused by about 140 species of microorganisms. Pathogenic microorganisms that most frequently cause mastitis can be divided into two groups based on their source: environmental pathogens (coliform bacteria and Streptococcus species other than Streptococcus agalactiae) and contagious pathogens (Str. agalactiae, Staphylococcus aureus, Mycoplasma spp. and

1) The 5,378 samples were investigated in the former Department of Pathophysiology of Reproduction and Mammary Gland, National Veterinary Research Institute in Pulawy, Division in Bydgoszcz, where the authors of the study had worked until 2014.
Corynebacterium bovis). The source of environmental bacteria is the habitat of the cow while the source of contagious pathogens are infected mammary glands. The identification of pathogens causing mastitis is important for disease control and epidemiological studies. The studies regarding the occurrence of mastitis pathogens were performed in several countries worldwide $(19,21,27)$. However, a survey on mastitis has not been conducted on a larger scale in Poland. The research carried out in recent years generally included one group of microorganisms, single cow herds or regions $(2,10,17)$. Changing breeding conditions, consumer expectations with regard to milk and milk products, breeding and veterinary practices, and tasks arising out of international economic and scientific cooperation require knowledge of the health status of food-producing animals.

This research paper addresses the hypothesis that the incidence of various bovine mastitis pathogens is 
subject to change over time and across regions. The aim of the study was to determine the pathogen species that are currently the etiological agents of mastitis in Polish dairy herds, and their prevalence depending on the region.

\section{Material and methods}

The study was conducted in the period 2009-2017 and included the samples collected from all 16 provinces of Poland. Over seven years 38,852 milk samples were obtained from 22,587 cows with clinical and subclinical mastitis. The samples were collected by veterinarians or farmers and selected after clinical examination and using the California Mastitis Test (CMT). Milk samples were collected with aseptic techniques in accordance with National Mastitis Council guidelines (21). Prior to collection of milk samples, the udder and teat were washed and dried and then the teat ends were disinfected with $70 \%$ ethyl alcohol. The first streams of milk were discarded before sample collecting. The samples were cooled and immediately transported to the laboratory. Ten microlitres of milk were plated as soon as possible on sheep blood agar. Milk samples were cultured using standard microbiological methods as described earlier $(11,30)$. A milk sample was classified as positive for S. aureus and Str. agalactiae when at least one characteristic colony was identified. Other microorganisms were considered as etiological agents of mastitis if more than three colonies were observed. Microorganisms were initially identified by colony morphology, haemolytic pattern and Gram staining (Color Gram 2 kit, bioMérieux, F-69280 Marcy-l'Etoile, France). For Gram-positive cocci, a catalase test was carried out to differentiate catalase-negative streptococci and enterococci from catalase-positive staphylococci. $S$. aureus were confirmed based on haemolytic patterns and a positive tube test for free coagulase (BIOMED, 00-725 Warszawa, Chełmska 30/34, Poland). A positive Christie, Atkins, Munch-Petersen (CAMP) test and the lack of esculin hydrolysis on esculin-containing Edwards medium (17) were used to differentiate Str. agalactiae from other streptococci. Enterococci were initially identified with the use of bile esculin agar (Biocorp, Parc technologique Lavaur la Béchade 63500 Issoire, France). Gram-negative bacilli were identified based on the cultural and morphological characteristics, growth on MacConkey agar (Oxoid, Wade Road Basingstoke Hampshire RG24 8PW United Kingdom), indole production and oxidase test (bioMérieux, Marcyl'Etoile, France). The species were determined using API biochemical tests (bioMérieux, Marcy-l'Etoile, France). Coryneform bacteria (Corynebacterium bovis, Trueperella pyogenes) and Listeria monocytogenes were initially identified based on colony morphology and microscopic view. The identification was confirmed using API test (bioMérieux, Marcy-l'Etoile, France) (17). Presumptive yeast and algae colonies were inoculated on Sabouraud dextrose agar (Oxoid, Hampshire, United Kingdom) and confirmed by microscopic observations. Species identification of Prototheca was based mainly upon morphological characterization of cultures, smears stained with Gram or methylene blue, resistance to clotrimazole and carbohydrate assimilation profiling $(6,17)$. Contaminated samples were defined as a mixed growth when three or more different species were isolated (except for $S$. aureus and Str. agalactiae). No growth samples were described when no colonies were observed after $72 \mathrm{~h}$ of incubation and after culture in Brain Heart Infusion broth (Oxoid, Hampshire, United Kingdom).

\section{Results and discussion}

Table 1 presents the distribution of milk samples in all Polish provinces. The largest number of samples was derived from Kuyavia-Pomerania (26.7\%), Wielkopolskie (17.2\%) and Lublin (15.1\%) provinces, and the least from West Pomerania $(0.6 \%)$ and Pomerania $(0.9 \%)$.

Table 2 shows distribution of pathogens as etiological agents of bovine mastitis. Of the 38,852 quarter milk samples cultured, 29,859 (76.8\%) were positive for pathogens (bacteria, yeasts and algae) including contaminated samples $(8.8 \%)$. No growth was observed in 8,993 (23.1\%) of the samples. The most commonly isolated pathogens were Gram-positive catalasenegative cocci (GPCNC) $(12,491$ isolates, $32.15 \%$ of the samples). This group of bacteria included 1017 isolates of Str. agalactiae (2.6\%) and 11,474 other non-infectious GPCNC (29.5\%). The most prevalent mastitis streptococci were environmental streptococci. Among the isolates identified to the species level, 5751 isolates (14.8\%) were Str. uberis and 2758 isolates (7.1\%) were Str. dysgalactiae. Enterococcus spp. were isolated from $2.8 \%$ of the samples. Other environmental streptococci not identified to the species level and nonagalactiae streptococci constituted $4.8 \%$ of all samples.

Tab. 1. Origin of $\mathbf{3 8 , 8 5 2}$ milk samples from clinical and subclinical cases of mastitis across Polish provinces

\begin{tabular}{|r|l|r|r|}
\hline No & \multicolumn{1}{|c|}{ Province } & $\begin{array}{c}\text { Number of } \\
\text { samples }\end{array}$ & \multicolumn{1}{c|}{$\%$} \\
\hline 1 & Dolnośląskie & 1092 & 2.8 \\
\hline 2 & Kujawsko-pomorskie & 10373 & 26.7 \\
\hline 3 & Lubelskie & 5890 & 15.1 \\
\hline 4 & Lubuskie & 687 & 1.7 \\
\hline 5 & Lódzkie & 424 & 1.1 \\
\hline 6 & Małopolskie & 1172 & 3.0 \\
\hline 7 & Mazowieckie & 3526 & 9.1 \\
\hline 8 & Opolskie & 1797 & 4.6 \\
\hline 9 & Podkarpackie & 456 & 1.2 \\
\hline 10 & Podlaskie & 2854 & 7.3 \\
\hline 11 & Śląskie & 1625 & 4.2 \\
\hline 12 & Świetokrzyskie & 812 & 2.1 \\
\hline 13 & Warmińsko-mazurskie & 828 & 2.1 \\
\hline 14 & Wielkopolskie & 6701 & 17.2 \\
\hline 15 & Pomorskie & 368 & 0.9 \\
\hline 16 & Zachodniopomorskie & 247 & 0.6 \\
\hline & Total & 38852 & 100.0 \\
\hline
\end{tabular}


Tab. 2. Distribution of mastitis pathogens in 38,852 milk samples from 22,587 cows with clinical and subclinical mastitis from mastitis cases

\begin{tabular}{|l|r|r|}
\hline \multicolumn{1}{|c|}{ Group of microorganisms } & Frequency & $\begin{array}{c}\text { Percentage of } \\
\text { samples (\%) }\end{array}$ \\
\hline Gram-positive catalase-negative cocci & 12491 & 32.15 \\
\hline Str. agalactiae & 1017 & 2.61 \\
\hline Other ${ }^{1}$ & 11474 & 29.53 \\
\hline Staphylococcus spp. & 9564 & 24.61 \\
\hline S. aureus & 2360 & 6.07 \\
\hline Coagulase-negative staphylococci & 7204 & 18.54 \\
\hline Gram-negative bacteria & 2485 & 6.39 \\
\hline \multicolumn{1}{|c|}{ Enterobacteriaceae ${ }^{2}$} & 1703 & 4.38 \\
\hline Gram-negative non-fermentative bacilli & 782 & 2.01 \\
\hline Coryneform bacteria and Listeria monocytogenes & 774 & 1.99 \\
\hline Gram-positive bacilli & 249 & 0.64 \\
\hline Yeasts & 394 & 1.01 \\
\hline Prototheca spp. & 483 & 1.24 \\
\hline Culture-negative & 8993 & 23.14 \\
\hline Contamination & 3419 & 8.80 \\
\hline Total & 38852 & 100.00 \\
\hline
\end{tabular}

Explanations: ${ }^{1}$ Among identified to the species level 5751 isolates (14.8\%) were Str. uberis, 2758 (7.1\%) Str. dysgalactiae and 1864 (4.8\%) Str. spp. isolates. Enterococcus spp. were isolated from 1101 (2.8\%) samples. ${ }^{2}$ Enterobacteriaceae isolates identified to the species/genus level included - E. coli (1074; 2.7\%), Klebsiella spp. (194; 0.5\%), Serratia spp. (155; 0.4\%), Enterobacter spp. (117; 0.3\%), Proteus spp. (133; $0.3 \%)$ and Citrobacter spp. (30;0.007\%)

The second largest group of the pathogens included staphylococci that were isolated from 9564 of the samples (24.6\%). Among them 2360 (6.1\%) belonged to the $S$. aureus species and $7204(18.5 \%)$ were coagulase-negative staphylococci (CNS).

A significant group of mastitis pathogens were Gram-negative bacteria (2485 isolates, 6.4\%), which comprised Escherichia coli (1074, 2.7\%), Klebsiella spp. (194, 0.5\%), Serratia spp. (155, 0.4\%), Proteus spp. (133, 0.3\%), Enterobacter spp. (117, 0.3\%) and Citrobacter spp. (30, 0.07\%). The most prevalent nonfermentative Gram-negative bacilli (NFB) were Pseudomonas spp. (135, 0.3\%), Aeromonas spp. (86, $0.2 \%)$, Pasteurella multocida $(3,0.01 \%)$ and others (558, 1.4\%).

Coryneform bacteria occurred in $774(2.0 \%)$ samples. Besides Corynebacterium bovis (422 isolates, $1.1 \%$ ) and other Corynebacterium spp. (135 isolates, $0.3 \%$ ), Trueperella pyogenes was detected in 210 milk samples $(0.5 \%)$. To this group we also included Listeria monocytogenes, which were found in 7 mastitis cases $(0.01 \%)$.

A total of $394(1.0 \%)$ samples were positive for yeasts (no moulds were isolated). Among positive samples genus Candida predominated (91.6\% of yeast samples). Algae Prototheca genus was detected in 483 milk samples (1.2\%). All of the isolates were identified as $P$. zopfii.

The regions with the highest number of cows infected with Str. agalactiae were the Podlaskie $(22.3 \%)$ and Mazowieckie (17.3\%) regions, whereas the lowest occurrence of this pathogen was observed in Wielkopolskie (7.6\%). S. aureus were isolated most frequently in herds localized in Mazowieckie and Lubelskie regions (14.2\% and $15.5 \%$, respectively) and less often in Małopolskie (8.3\%) and Wielkopolskie (9.8\%). The other mastitis pathogens occurred with similar frequencies in all provinces. The diversity in the number of samples is associated with the contribution of particular regions in population of dairy cattle. According to the Polish Central Statistical Office, the largest share in the milk cow population were in the Mazowieckie, Podlaskie and Wielkopolskie provinces and the smallest in Lubuskie, Podkarpackie, Zachodniopomorskie. Laboratories, where the samples were taken, are localised in Kujawsko-pomorskie, Wielkopolskie and Lubelskie regions.

Many factors affect the occurrence of mastitis on dairy farms. Almost any microbe that can opportunistically invade tissue and cause infection can cause mastitis. The primary sources of infection for most pathogens may be regarded as contagious or environmental. In our study the most common microorganisms isolated from milk were environmental streptococci, CNS, coagulase-positive staphylococci ( $S$. aureus) and Enterobacteriaceae (mainly E. coli). Other isolated organisms were Str. agalactiae, Gram-negative and Gram-positive bacilli, Prototheca spp., yeasts, C. bovis and T. pyogenes. These microorganisms were also isolated in our previous study (18). The results are in agreement with the data reported by other authors, although percentages of each species sometimes differ fundamentally $(2,8,10,24,25,31)$.

Streptococci other than Str. agalactiae are environmental bacteria responsible for bovine mastitis. In our study environmental streptococci were the most frequently isolated pathogens from samples of milk from cows with mastitis. The primary sources of environmental streptococci bacteria that cause mastitis are environmental sites on the farm such as bedded housing and calving areas, standing water and soil in open areas. Another important source of environmental streptococci bacteria is the cow. Environmental streptococci have been cultured from the mouth, teat, abdomen and udder skin, bovine faeces and from straw bedding of cattle (5). The occurrence of mammary gland inflammation caused by contagious pathogen $S$. agalactiae has decreased over the last few decades due to introduction of mastitis control programmes $(16,18)$ and has been almost eradicated $(0-0.2 \%)$ from 
dairy herds in many countries $(4,8,23)$. Recently, in some European countries such as Denmark and Finland the frequency of $S$. agalactiae isolation from bovine mastitis milk has increased again (1).

Among Gram-positive catalase-negative cocci identified to the genus level, Enterococcus spp. were less common mastitis pathogens than Str. uberis and Str. dysgalactiae, which is in agreement with our previous study (18) and studies performed by the other authors $(8,10,22)$. Enterococci colonize the skin of the animals udder in a significant number, therefore it was suggested that these pathogens may be considered as contaminants of the milk samples and not as etiological agents of mastitis. However, further studies revealed that these bacteria have pathogenic potential in mastitis pathogenesis in cows in different stages of lactation (36).

Coagulase-negative staphylococci constitute a heterogeneous group with a large number of species and are pathogens frequently isolated from mastitis in dairy cows. The prevalence of CNS as etiological agents of mastitis is higher in primiparous than in older cows. These microorganisms have been considered as minor pathogens which can damage udder tissue and cause the decrease in milk production and milk quality and the increase in the somatic cell count $(16,26)$. Resistance to various antimicrobials is more common in CNS than in $S$. aureus, but CNS mastitis responds much better to antimicrobial treatment than $S$. aureus mastitis (32). This group of bacteria is a common cause of milk sample contamination and their isolation could also suggest poor sampling technique or poor teat end hygiene, or both (25). This may be confirmed by studies performed by Tenhagen et al. (33), who showed that $\mathrm{CNS}$ were the most frequently isolated microorganisms (46.8\% of samples) from clinically healthy quarters of primiparous.

$S$. aureus is now the most common mastitis pathogen difficult to control in dairy herds. Although S. aureus is easily identified and not intractable to cultivate, it needs rapid and sensitive tests. Inflammations caused by $S$. aureus are usually chronic and occur without clinical symptoms. The pathogenicity of $S$. aureus is the result of the expression of a number of virulence factors that contribute to adhesion, escaping host defenses and spreading in a host organism $(3,20,29)$. In this study we showed the presence of $S$. aureus in $6.4 \%$ of the samples, while in our previous research in $8.6 \%$ (18). This is in accordance with the data reported by Wilson et al. (37) (9.1\% of samples) and Tenhagen et al. (33) (5.0\% of infected quarters). A higher percentage of $S$. aureus was demonstrated in milk samples from clinical cases in primiparous $(10.0 \%)$ and older cows $(11.7 \%)(33)$.

Mastitis caused by Gram-negative bacteria is a growing problem in modern and well-managed dairy herds. Coliforms, which are lactose-fermenting
Gram-negative rods within the Enterobacteriaceae family, of the Enterobacterales order, belong to the most common causes of severe mastitis. Coliforms include E. coli, Klebsiella pneumoniae, Enterobacter cloacae and other species. The prevalence of coliform infection is low, constituting only $2-4 \%$ of mastitis cases; however, severe clinical mastitis is common and frequently fatal. The most important and most common pathogen that causes acute inflammation of the udder is E. coli. Apart from E. coli a great significance also have Klebsiella spp. and Serratia spp. Data reported by Schukken et al. (28) showed that Klebsiella spp. caused the most severe cases, just behind the $E$. coli, while much less clinical severity is observed in Serratia spp. infection. In this study the coliform species mentioned above were isolated the most frequently, which is in accordance with other reports $(16,11)$.

Trueperella pyogenes is a Gram-positive, non-sporeforming, opportunistic pathogen with a broad range of virulence factors (39). This bacterium typically causes mastitis in dry cows or heifers prior to calving and rarely in lactating cows. Infections intensify particularly during the summer or humid weather. In this study $T$. pyogenes were isolated at low frequency, but all cases were severe with malodorous, purulent secretion, high somatic cell count, reduction in milk yield, high rate of mammary gland dysfunction.

A decrease in Corynebacterium spp. (1.2\%) infection has been observed in comparison with the years 2003-2005 (3.8\%) (18). In our study C. bovis was the causative agent of bovine mastitis in $1.1 \%$ of the cases, which is in contrast to the results obtained from the study including nine dairy herds in North-East Poland $(5.4 \%)(31)$. C. bovis is traditionally considered to be a minor mastitis pathogen, however it has become more common in Finland in 2004 (34.4\%) (24).

Yeast infections of the mammary gland usually occur as sporadic infections in a limited number of cows, or as an outbreak affecting a large number of animals. Yeasts are ubiquitous in the environment of dairy farms and may also be introduced into the udder together with contaminated drugs prepared in non-sterile conditions or due to the use of poor infusion techniques. However, yeast mastitis in cows is most frequently associated with prior antibiotic treatment of bacterial mastitis $(12,13)$. The incidence of yeast mastitis is usually low; however in tropical countries it may be considerably higher. In our study yeasts were isolated at a frequency of $1.0 \%$ from the milk samples. The isolation of these microorganisms from cattle affected with mastitis has also been reported in Brazil (7), Mexico (38) http:// www.elsevier.es/en-revista-revista-iberoamericanamicologia-290-articulo-yeasts-isolation-from-bovinemammary-S1130140611000271 - aff0005and Algeria (14). The mentioned authors detected yeasts in 10.2$25.75 \%$ of the milk samples. The percentages of yeast isolation in surveys conducted in many countries dif- 
fer significantly. These differences may result from the climate, the management of the herd, zoohygenic conditions in the barn, and many other reasons.

In the dairy farm environment, Prototheca spp. are especially abundant in muddy or wet outdoor runs or lots, resting areas, paths where animals are driven, and pastures contaminated with slurry. The disease has been recognized globally but only since the late 1990s has it received serious attention by the veterinary community due to its escalating occurrence (9).

In conclusion, the study performed in Poland in the period 2009-2017 found that the environment was the main source of pathogens, with greater involvement of environmental streptococci and CNS. Based on the results, we believe that there is a large diversity of occurrence and distribution of pathogens which are dependant on the geographical location and number of dairy farms in the province.

\section{References}

1. Barkema H. W., Green M. J., Bradley A. J., Zadoks R. N.: Invited review: The role of contagious disease in udder health. J. Dairy Sci. 2009, 92, 4717-4729.

2. Bochniarz M., Wawron W., Szczubiat M.: Coagulase-negative staphylococci (CNS) as an aetiological factor of mastitis in cows. Pol. J. Vet. Sci. 2013, 16, 487-492.

3. Bradley A.: Bovine mastitis: an evolving disease. Vet. J. 2002, 164, 116-128.

4. Bradley A., Leach K. A., Breen J. E., Green L. E., Green M. J.: Survey of the incidence and aetiology of mastitis on dairy farms in England and Wales. Vet. Rec. 2007, 160, 253-258

5. Bramley A. J.: Sources of Streptococcus uberis in the dairy herd. I. Isolation from bovine faeces and from straw bedding of cattle. J. Dairy Res. 1982, 49 , 369-373.

6. Casal M. J., Gutierrez J.: Simple new test for rapid differentiation of Prototheca wickerhamii from Prototheca zopfii. J. Clin. Microbiol. 1983, 18, 992-993.

7. dos Santos R. C., Marin J. M.: Isolation of Candida spp. from mastitic bovine milk in Brazil. Mycopathologia 2005, 159, 251-253.

8. Guélat-Brechbuehl M., Thomann A., Albini S., Moret-Stalder S., Reist M., Bodmer M., Michel A., Niederberger M. D., Kaufmann T.: Cross-sectional study of Streptococcus species in quarter milk samples of dairy cows in the canton of Bern, Switzerland. Vet. Rec. 2010, 167, 211-215.

9. Jagielski T., Bakula Z., Di Mauro S., Ccasciari C., Cambiotti V., Krukowski H., Turchetti B., Ricchi M., Manuali E., Buzzini P.: A comparative study of the in vitro activity of iodopropynyl butylcarbamate and amphotericin B against Prototheca spp. isolates from European dairy herds. J. Dairy. Sci. 2017, 100, 7435-7445.

10. Kalmus P., Aasmäe B., Kärssin A., Orro T., Kask K.: Udder pathogens and their resistance to antimicrobial agents in dairy cows in Estonia. Acta Vet. Scand. 2011, 53, 4

11. Koivula M., Pitkälä A., Pyörälä S., Mäntysaari E.: Distribution of bacteria and seasonal and regional effects in a new database for mastitis pathogens in Finland. Acta Agric. Scand. A 2007, 57, 89-96.

12. Krukowski H., Lisowski A.: Occurrence of yeast mastitis in cows in relation to the type of dairy farm, system of milking and maintenance system of cows. Med. Weter. 2010, 66, 339-343.

13. Krukowski H., Lisowski A., Różański P., Skórka A.: Yeasts and algae isolated from cows with mastitis in the south-eastern part of Poland. Pol. J. Vet. Sci. 2006, 9, 181-184.

14. Ksouri S., Djebir S., Hadef Y., Benakhla A.: Survey of bovine mycotic mastitis in different mammary gland statuses in two north-eastern regions of Algeria. Mycopathologia 2015, 179, 327-331.

15. Leroy F., Van Coillie E., Braem G., Piessens V., Verbist B., De Vuyst L., De Vliegher $S$.: Subtyping of Staphylococcus haemolyticus isolates from milk and corresponding teat apices to verify the potential teat-skin origin of intramammary infections in dairy cows. J. Dairy Sci. 2015, 98, 7893-7898.

16. Makovec J. A., Ruegg P. L.: Results of milk samples submitted for microbiological examination in Wisconsin from 1994 to 2001. J. Dairy Sci. 2003, 86, 3466-3472.
17. Malinowski E., Kłossowska A.: Diagnostyka zakażeń i zapaleń wymienia [In English: Diagnostics of intramammary infections]. Published by the National Veterinary Research Institute, Pulawy, Poland 2002.

18. Malinowski E., Lassa H., Kłossowska A., Smulski S., Markiewicz H., Kaczmarowski M.: Etiological agents of dairy cows mastitis in western part of Poland. Pol. J. Vet. Sci. 2006, 9, 191-194.

19. Nam H. M., Kim J. M., Lim S. K., Jang K. C., Jung S. C.: Infectious aetiologies of mastitis on Korean dairy farms during 2008. Res. Vet. Sci. 2010, 88, 372-374.

20. Nickerson S. C.: Preventing new Staphylococcus aureus mastitis infections. Vet. Med. 1993, 88, 368-374.

21. NMC (National Mastitis Council) Laboratory Handbook on Bovine Mastitis. NMC Inc., Madison, WI, USA 1999.

22. Olde Riekerink R. G. M., Barkema H. W., Kelton D. F., Scholl D. T.: Incidence rate of clinical mastitis on Canadian dairy farms. J. Dairy Sci. 2008, 91, 1366-1377 .

23. Østerås $O$., Sølverød L., Reksen O.: Milk culture results in a large Norwegian survey-effects of season, parity, days in milk, resistance, and clustering. J. Dairy Sci. 2006, 89, 1010-1023.

24. Pitkälä A., Haveri M., Pyörälä S., Myllys V., Honkanen-Buzalski T.: Bovine Mastitis in Finland 2001 - prevalence, distribution of bacteria, and antimicrobial resistance. J. Dairy Sci. 2004, 87, 2433-2441.

25. Pyörälä S., Taponen S.: Coagulase-negative staphylococci emergering mastitis pathogens. Vet. Microbiol. 2009, 134, 3-8.

26. Raspanti C. G., Bonetto C. C., Vissio C., Pellegrino M. S., Reinoso E. B. Dieser S. A., Bogni C. I., Larriestra A. J., Odierno L. M.: Prevalence and antibiotic susceptibility of coagulase-negative Staphylococcus species from bovine subclinical mastitis in dairy herds in the central region of Argentina. Rev. Argent. Microbiol. 2016, 48, 50-56.

27. Sampimon O., Barkema H. W., Berends I., Sol J., Lam T.: Prevalence of intramammary infection in Dutch dairy herds. J. Dairy Res. 2009, 76, 129-136.

28. Schukken Y. H., Bennett G. J., Zurakowski M. J., Sharkey H. L., Rauch B. J., Thomas M. J., Ceglowski B., Saltman R. L., Belomestnykh N., Zadoks R. N.: Randomized clinical trial to evaluate the efficacy of a 5-day ceftiofur hydrochloride intramammary treatment on nonsevere Gram-negative clinical mastitis. J. Dairy Sci. 2011, 94, 6203-6215.

29. Smith G. W., Lyman R. L., Anderson K. K.: Efficacy of vaccination and antimicrobial treatment to eliminate chronic intrammmary Staphylococcus aureus infections in dairy cattle. J. Am. Vet. Med. Assoc. 2006, 228, 422-425.

30. Smulski S., Malinowski E., Kaczmarowski M., Lassa H.: Occurrence, forms and etiologic agents of mastitis in Poland depending on size of farm. Med. Weter. 2011, 67, 190-193.

31.Sztachańska M., Barański W., Janowski T., Pogorzelska J., Zduńczyk S.: Prevalence and etiological agents of subclinical mastitis at the end of lactation in nine dairy herds in North-East Poland. Pol. J. Vet. Sci. 2016, 19, 119-124.

32. Taponen S., Pyörälä S.: Coagulase-negative staphylococci as cause of bovine mastitis - not so different from Staphylococcus aureus? Vet. Microbiol. 2009, 134, 29-36.

33. Tenhagen B. A., Hansen I., Reinecke A., Heuwieser W.: Prevalence of pathogens in milk samples of dairy cows with clinical mastitis and in heifers at first parturition. J. Dairy Res. 2009, 76, 179-187.

34. Tenhagen B. A., Köster G., Wallmann J., Heuwieser W.: Prevalence of mastitis pathogens and their resistance against antimicrobial agents in dairy cows in Brandenburg, Germany. J. Dairy Sci. 2006, 89, 2542-2551.

35. Watts J. L.: Etiological agents of bovine mastitis. Vet. Microbiol. 1988, 16, 41-66.

36. Werner G., Fleige C., Fessler A. T., Timke M., Kostrzewa M., Zischka M., Peters T., Kaspar H., Schwarz S.: Improved identification including MALDITOF mass spectrometry analysis of group D streptococci from bovine mastitis and subsequent molecular characterization of corresponding Enterococcus faecalis and Enterococcus faecium isolates. Vet. Microbiol. 2012, 160, 162-169 .

37. Wilson D., Gonzales R. N., Das H. H.: Bovine mastitis pathogens in New York and Pennsylvania: prevalence and effect on somatic cell count and milk production. J. Dairy Sci. 1997, 80, 2592-259.

38. Zaragoza C. S., Olivares R. A., Watty A. E., Moctezuma Ade L., Tanaca L. V. Yeasts isolation from bovine mammary glands under different mastitis status in the Mexican High Plateu. Rev. Iberoam. Micol. 2011, 28, 79-82.

39. Zastempowska E., Lassa H.: Genotypic characterization and evaluation of an antibiotic resistance of Trueperella pyogenes (Arcanobacterium pyogenes) isolated from milk of dairy cows with clinical mastitis. Vet. Microbiol. 2012, $161,153-158$.

Corresponding author: Henryk Krukowski DVM, PhD Hab., Akademicka 13 Street, 20-950 Lublin, Poland; e-mail:henryk.krukowski@up.lublin.pl 